\title{
Pulmonary Hemodynamics and Ventilation in Patients With COVID-19-related Respiratory Failure and ARDS
}

\section{André Becker}

Universitatsklinikum des Saarlandes und Medizinische Fakultat der Universitat des Saarlandes

Frederik Seiler

Universitatsklinikum des Saarlandes und Medizinische Fakultat der Universitat des Saarlandes

\section{Ralf M. Muellenbach}

Universitatsklinikum des Saarlandes und Medizinische Fakultat der Universitat des Saarlandes

\section{Guy Danziger}

Universitatsklinikum des Saarlandes und Medizinische Fakultat der Universitat des Saarlandes

\section{Sebastian Mang}

Universitatsklinikum des Saarlandes und Medizinische Fakultat der Universitat des Saarlandes

Albert Omlor

Universitatsklinikum des Saarlandes und Medizinische Fakultat der Universitat des Saarlandes

Christophe Jentgen

Universitatsklinikum des Saarlandes und Medizinische Fakultat der Universitat des Saarlandes

\section{Maren Kamphorst}

Universitatsklinikum des Saarlandes und Medizinische Fakultat der Universitat des Saarlandes

\section{Holger Wehrfritz}

Universitatsklinikum des Saarlandes und Medizinische Fakultat der Universitat des Saarlandes

\section{Christopher Lotz}

Universitatsklinikum Wurzburg

\section{Thilo Mertke}

Universitatsklinikum des Saarlandes und Medizinische Fakultat der Universitat des Saarlandes

\section{Heinrike Wilkens}

Universitatsklinikum des Saarlandes und Medizinische Fakultat der Universitat des Saarlandes

\section{Robert Bals}

Universitatsklinikum des Saarlandes und Medizinische Fakultat der Universitat des Saarlandes

Philipp M. Lepper ( $\square$ philipp.lepper@uks.eu )

Dept. of Internal Medicine V - Pneumology and Critical Care Medicine ECLS Center Saar University Hospital of Saarland Kirrbergerstr. 166421 Homburg https://orcid.org/0000-0003-3620-0912 
Keywords: Acute Respiratory Distress Syndrome, Mechanical Ventilation, Novel Coronavirus Disease 2019, COVID-19, Pulmonary artery catheter

Posted Date: September 2nd, 2020

DOI: https://doi.org/10.21203/rs.3.rs-66763/v1

License: (c) (1) This work is licensed under a Creative Commons Attribution 4.0 International License. Read Full License

Version of Record: A version of this preprint was published at Journal of Intensive Care Medicine on March 8th, 2021. See the published version at https://doi.org/10.1177/0885066621995386. 


\section{Abstract}

Background: It has been suggested that COVID-19-associated severe respiratory failure (CARDS) might differ from usual acute respiratory distress syndrome (ARDS) due to failing auto-regulation of pulmonary vessels and higher shunt. We sought to investigate pulmonary hemodynamics and ventilation properties in patients with CARDS compared to patients with ARDS of pulmonary origin.

Methods: Retrospective analysis of prospectively collected data of consecutive adults with laboratoryconfirmed severe acute respiratory syndrome coronavirus 2 patients treated on our ICU in 04/2020 and comparison of the data to matched controls with ARDS due to respiratory infections treated on our ICU from $01 / 2014$ to $08 / 2019$ and for whom pulmonary artery catheter data were available.

Results: CARDS patients $(n=10)$ had similar ventilation characteristics as compared to ARDS $(n=10)$ patients. Still, mechanical power applied by ventilation was significantly higher in CARDS patients (23.4 \pm $8.9 \mathrm{~J} / \mathrm{min})$ than in ARDS $(15.9 \pm 4.3 \mathrm{~J} / \mathrm{min} ; \mathrm{p}<0.05)$. COVID-19 patients had similar pulmonary artery pressure but significantly lower pulmonary vascular resistance, as cardiac output was higher in CARDS vs. ARDS patients $(p<0.05)$. Shunt fraction and dead space were similar in CARDS compared to ARDS $(\mathrm{p}>0.05)$ and was in both groups correlated with hypoxemia. The arterio-venous $\mathrm{pCO}_{2}$ difference $\left(\mathrm{DpCO}_{2}\right)$ was elevated (CARDS $5.5 \pm 2.8 \mathrm{mmHg}$ vs. ARDS $4.7 \pm 1.1 \mathrm{mmHg} ; \mathrm{p}>0.05$ ) as was $\mathrm{P}_{(\mathrm{v}-\mathrm{a})} \mathrm{CO}_{2} / \mathrm{C}_{(\mathrm{a}-\mathrm{v})} \mathrm{O}_{2}$ ratio (CARDS mean $2.2 \pm 1.5$ vs. ARDS $1.7 \pm 0.8 ; p>0.05$ ).

Conclusions: Respiratory failure in COVID-19 patients seems to differ only slightly from ARDS regarding ventilation characteristics and pulmonary hemodynamics. Differences are mainly due to increased $\mathrm{CO}_{2}$ production in CARDS patients. Our data indicate microcirculatory dysfunction. More data needs to be collected to assure these findings and gain more pathophysiological insights in COVID-19 and respiratory failure.

\section{Introduction}

Severe acute respiratory syndrome-Coronavirus 2 (SARS-CoV-2) causes a disease termed COVID-19. Symptoms are ranging from mild upper airway symptoms to acute respiratory distress syndrome (ARDS). There are hints that some characteristics of respiratory failure in COVID-19 patients are different from acute respiratory distress syndrome as we know it from other causes e.g. viral or bacterial infection. We and others observed relatively normal respiratory mechanics ${ }^{1}$ despite poor oxygenation. It has been suggested that in COVID-19-related ARDS (CARDS), this is in part due to defective pulmonary vasoregulation so that hypoxic pulmonary vasoconstriction does not occur, leading to ventilation/ perfusion-mismatch and consequently may lead to profound hypoxemia ${ }^{2}$. These findings and hypotheses led to the question if our present understanding of ARDS with regard to pulmonary hemodynamics and right heart failure can be transferred to CARDS. 
Previous reports suggest that COVID-19 induces the massive release of cytokines, including interleukin 6 (IL-6) and hence it has been suggested to treat COVID-19 by IL- 6 blockade. Increased pulmonary vascular resistance is a consequence of various factors including hypercarbia, acidosis, inflammation, vascular endothelial proliferation ${ }^{3}$ and hypoxic pulmonary vasoconstriction. There is ample evidence that perivascular inflammation triggered by various mediators, including IL-6, contributes to pulmonary vascular disease resulting in pulmonary hypertension. Pulmonary hypertension due to increased pulmonary vascular resistance is a common finding in ARDS ${ }^{4,5}$. The exact prevalence of pulmonary hypertension in ARDS is not known ${ }^{4}, 6$ and varies considerably across studies. These differences may result from general differences between cohorts, cardiovascular comorbidities, aetiology of ARDS and therapeutic interventions (e.g. permissive hypercapnia). ARDS normally is characterized by a low-pressure pulmonary oedema, shunt-related hypoxemia and reduced aerated lung volume causing severely impaired lung compliance. It is widely accepted, that ARDS patients with elevated pulmonary pressure are at risk of dying from right heart failure ${ }^{7}$.

In the present study, we compared CARDS patients to ARDS patients with regard to hemodynamic and derived physiologic parameters, to elucidate, if there are distinct features in CARDS that separate CARDS and ARDS with regard to ventilation and pulmonary hemodynamics.

\section{Methods}

This observational case-control study describes data of extended hemodynamic monitoring via pulmonary artery catheterization of 10 consecutive patients with laboratory confirmed COVID-19-related respiratory failure (CARDS) treated on our tertiary-care ICU in April 2020. Patients were mainly transferred for the possibility of ECMO support or for further management from hospitals under the surge of COVID19 in near-by France. Further, we gathered the characteristics of mechanical ventilation, arterial blood gas and laboratory findings in these patients. Characteristics of ventilation and pulmonary hemodynamics were 1:1 compared to patients with ARDS due to pneumonia $(n=10)$. Groups were matched according to disease severity using the simplified acute physiology score II (SAPS II), $\mathrm{PO}_{2} / \mathrm{F}_{i} \mathrm{O}_{2}$ ratio, age, sex and body mass index (BMI).

Ventilation was in pressure controlled mode in all patients. Generally, we targeted a protective ventilation approach, aiming at driving pressures below $15 \mathrm{cmH}_{2} \mathrm{O}$ and tidal volumes $\mathrm{V}_{\mathrm{T}}$ of approx. $6 \mathrm{~mL}$ per kg of predicted bodyweight (PBW). Mean arterial pressure target is mainly $60-65 \mathrm{mmHg}$, if physiologic aims are reached. These include capillary refill time (i.e. warm periphery), urinary output $(\geq 0.5 \mathrm{ml} / \mathrm{kg} / \mathrm{h}$ ) or lactate levels $(\leq 2.0 \mathrm{mmol} / \mathrm{l})$. Norepinephrine was the vasopressor of choice in patients with $\mathrm{pH} \geq 7.25$. Inotrope use was initiated, if $\mathrm{S}_{\mathrm{cv}} \mathrm{O}_{2}$ was below $65 \%$ despite adequate hemoglobin levels.

\section{Measurements and data recording}

Extended hemodynamic monitoring was established synchronized with collection of blood gas analysis. Briefly, after inserting a sheath catheter, a Swan-Ganz catheter (Edwards Lifesciences Corp., Irvine, CA, 
USA) was advanced to the pulmonary artery till a curve characteristic for pulmonary capillary wedge pressure could be derived. Arterial and venous blood gases with parameters such as partial pressures of oxygen $\left(\mathrm{pO}_{2}\right)$ and carbon dioxide $\left(\mathrm{pCO}_{2}\right)$, hemoglobin, lactate, glucose, and $\mathrm{pH}$ were obtained via analysis on an ABL800 Blood Gas Analyzer (Radiometer, Copenhagen, Denmark).

Characteristics of ventilation correspond to the moment of data collection. Laboratory parameters were collected the same day of pulmonary artery catheterization. Protocols for hemodynamic measurement were identical for both cohorts.

\section{Calculation of hemodynamic and physiologic parameters}

Cardiac output (CO) was measured using pulmonary arterial catheters (PAC) with thermodilution technique. Cardiac index $(\mathrm{Cl})$ relates $\mathrm{CO}$ to body surface area, calculated according to Du Bois formula. The following variables were calculated: stroke volume $(\mathrm{SV}=\mathrm{CO} / \mathrm{HR}, \mathrm{mL})$; pulmonary pulse pressure (PP = sPAP-dPAP, $\mathrm{mmHg}$ ); transpulmonary pressure gradient (TPG = mPAP-PAWP, $\mathrm{mmHg}$ ); diastolic pressure gradient (DPG = dPAP-PAWP, $\mathrm{mmHg})$; pulmonary vascular resistance $(P V R=T P G / C O$ Wood units: $\mathrm{mmHg}{ }^{\star} \mathrm{min} / \mathrm{L}$, or $\left.\mathrm{mmHg}{ }^{\star} \mathrm{S} / \mathrm{mL}\right)$; pulmonary arterial compliance $\left(\mathrm{C}_{\mathrm{PA}}=\mathrm{SV} / \mathrm{PP}, \mathrm{mL} / \mathrm{mmHg}\right)$; time constant (RC time, $\left.\tau=C_{P A} \times P V R, s\right)$.

Further, we calculated the ratio of the venous-arterial $\mathrm{CO}_{2}$ gap to arterial-venous oxygen content difference $\left(\mathrm{P}_{(\mathrm{v}-\mathrm{a})} \mathrm{CO}_{2} / \mathrm{C}_{(\mathrm{a}-\mathrm{v})} \mathrm{O}_{2}\right)$ as $\left(\mathrm{P}_{\mathrm{v}} \mathrm{CO}_{2}-\mathrm{P}_{\mathrm{a}} \mathrm{CO}_{2}\right) /\left(\mathrm{C}_{\mathrm{a}} \mathrm{O}_{2}-\mathrm{C}_{\mathrm{v}} \mathrm{O}_{2}\right)$ with $\mathrm{C}_{\mathrm{a}} \mathrm{O}_{2}=\left(1.34 \mathrm{~mL} / \mathrm{g} \times \mathrm{S}_{\mathrm{a}} \mathrm{O}_{2} \times \mathrm{Hb}\right)+$ $\left(0.003 \mathrm{~mL} /(\mathrm{dL} * \mathrm{mmHg}) \times \mathrm{P}_{\mathrm{a}} \mathrm{O}_{2}\right)$ and $\mathrm{C}_{\mathrm{v}} \mathrm{O}_{2}=\left(1.34 \mathrm{~mL} / \mathrm{g} \times \mathrm{S}_{\mathrm{v}} \mathrm{O}_{2} \times \mathrm{Hb}\right)+\left(0.003 \mathrm{~mL} /(\mathrm{dL} * \mathrm{mmHg}) \times \mathrm{P}_{\mathrm{v}} \mathrm{O}_{2}\right)$. $\mathrm{DO}_{2}$ was calculated as $\mathrm{CO} \times \mathrm{C}_{\mathrm{a}} \mathrm{O}_{2}$ and $\mathrm{VO}_{2}$ as $\mathrm{CO} \times\left(\mathrm{C}_{\mathrm{a}} \mathrm{O}_{2}-\mathrm{C}_{\mathrm{v}} \mathrm{O}_{2}\right) . \mathrm{P}(\mathrm{v}-\mathrm{a}) \mathrm{CO}_{2}$ gap was calculated as $\mathrm{P}_{\mathrm{v}} \mathrm{CO}_{2}$ - $\mathrm{P}_{\mathrm{a}} \mathrm{CO}_{2}$. Calculation of estimated dead space fraction was done using a rearranged alveolar gas equation $\mathrm{V}_{\mathrm{D}} / \mathrm{V}_{\mathrm{T}}=1-\left[\left(0.86 \mathrm{mmHg} \times \mathrm{VCO}_{2 \text { est }}\right) /\left(\mathrm{VE} \times \mathrm{P}_{\mathrm{a}} \mathrm{CO}_{2}\right)\right]$ where $\mathrm{VCO}_{\text {2est }}$ is the estimated $\mathrm{CO}_{2}$ production calculated gender specific from the Harris Benedict Eq. 8. Minute ventilation (VE) is obtained from the ventilator rate times expired tidal volume and $\mathrm{Pa}_{\mathrm{a}} \mathrm{O}_{2}, \mathrm{P}_{\mathrm{a}} \mathrm{CO}_{2}$ from arterial gas analysis. Ventilatory ratio (VR), as a measure for ventilator efficiency was calculated as $\left(\mathrm{VE} \times \mathrm{P}_{\mathrm{a}} \mathrm{CO}_{2}\right)$ divided by $(100 \mathrm{~mL} / \mathrm{min}$ $\times$ predicted body weight $(\mathrm{PBW} ; \mathrm{kg}) \times 40 \mathrm{mmHg}$ (expected $\left.\left.\mathrm{P}_{\mathrm{a}} \mathrm{CO}_{2}\right)\right)^{9}$. Predicted body weight was calculated according to the ARDSNet PBW calculator ${ }^{10}$. Pulmonary shunt fraction was calculated as $Q_{S} / Q_{T}=\left(C_{c} O_{2}{ }^{-}\right.$ $\left.\mathrm{C}_{\mathrm{a}} \mathrm{O}_{2}\right) /\left(\mathrm{C}_{\mathrm{c}} \mathrm{O}_{2}-\mathrm{C}_{\mathrm{v}} \mathrm{O}_{2}\right)$. Alveolar-arterial $\mathrm{O}_{2}$ gradient $\left(\mathrm{A}-\mathrm{aDO} \mathrm{O}_{2}\right)$ was calculated as $\left[\mathrm{F}_{\mathrm{i}} \mathrm{O}_{2} \times\right.$ (barometric pressure $\left.-47 \mathrm{mmHg})-\mathrm{P}_{\mathrm{a}} \mathrm{CO}_{2} / 0.81\right]-\left[\left(\mathrm{P}_{\mathrm{a}} \mathrm{O}_{2}+\right.\right.$ age in years $\left.\left./ 4^{\star} \mathrm{mmHg}\right)+4\right]$. Barometric pressure was recorded on the day of pulmonary artery catheterization.

Mechanical power applied by ventilation was calculated by multiplying each component of the equation of motion by the minute ventilation using the following equation: mechanical power $=0.098 \times$ tidal volumes $\times$ respiratory rate $\times($ Ppeak $-0.5 \times$ driving pressure $)$ in $\mathrm{J} / \mathrm{min}$.

\section{Statistical analysis}

Data are reported as median (range) or median (range; mean $\pm S D$ ), if not otherwise indicated. Statistical analysis was performed with GraphPad Prism 5.02 (GraphPad Software, Inc., La Jolla, CA). Unpaired t- 
test was used to test for differences between the groups as all groups showed Gaussian distribution in Kolmogorov-Smirnov test. P-values $<0.05$ were considered significant.

\section{Results}

\section{Baseline demographics and laboratory findings}

All patients in the CARDS group received mechanical ventilation as result of SARS-CoV-2 infection with pneumonia and respiratory failure. These patients were matched to a historical cohort of ARDS patients treated on our ICU. SAPS II Score was 42 in the COVID-19 group $(n=10)$, and 41 in the ARDS group $(n=$ 10). Patients in both groups had mild to severe ARDS, according to the Berlin classification of ARDS ${ }^{11}$. $\mathrm{P}_{\mathrm{a}} \mathrm{O}_{2} / \mathrm{F}_{\mathrm{i}} \mathrm{O}_{2}$ did not differ between the two groups (118 vs. 120 in median; $p>0.05$ ). Median age in CARDS patients was 62 years (range 59-71) compared to 71 in ARDS patients (range 45-85), $p>0.05$. Nine out of ten CARDS and eight out of ten ARDS patients were male. Three of ten COVID-19 patients had obesity $I^{\circ}$, three had normal BMI and 4 patients had light overweight, however there was no difference to ARDS patients. There was a statistically significant difference in body temperature during haemodynamic measurement. While ARDS patients had no fever (median $37.4^{\circ} \mathrm{C}$ ), every CARDS patient showed body temperature above $38.1^{\circ} \mathrm{C}$ (median $38.5^{\circ} \mathrm{C}$ ).

Clinical characteristics and laboratory findings of the patients are shown in Table 1. In CARDS patients, CRP and Interleukin- 6 was elevated. Procalcitonin was $0.69 \mathrm{ng} / \mathrm{mL}(0.09-276 \mathrm{ng} / \mathrm{mL})$ in median. CRP in ARDS patients was slightly lower than in CARDS (104 vs. 234, $p>0.05$ ). In CARDS D-Dimer levels were elevated with $3.2 \mathrm{mg} / \mathrm{L}$ (range $0.9-19.4 \mathrm{mg} / \mathrm{L}$ ). Thrombocytes levels were in normal range. Renal function (creatinine $1.13 \mathrm{mg} / \mathrm{dL}$ ) and liver function (bilirubin $1.15 \mathrm{mg} / \mathrm{dL}$ ) were slightly decreased in both groups. 
Table 1

Baseline characteristics and laboratory findings of CARDS patients $(N=10)$ compared to patients with ARDS due to pulmonary infections $(\mathrm{N}=10)$ with invasive hemodynamic measurement (Interleukin 6 and

PCT were not part of the laboratory routine for patients with usual ARDS at the time of evaluation).

\begin{tabular}{|c|c|c|c|}
\hline Laboratory findings & $\begin{array}{l}\text { CARDS; } N=10 \\
\text { median (range; mean } \pm \text { SD) }\end{array}$ & $\begin{array}{l}\text { ARDS; } N=10 \\
\text { median (range; mean } \pm \text { SD) }\end{array}$ & P Value \\
\hline Cause of ARDS & SARS-CoV2 & 7/10 CAP; $3 / 10$ HAP & \\
\hline SAPS & $42(29-54 ; 42 \pm 8)$ & $41(25-51 ; 38 \pm 8)$ & $>0.05$ \\
\hline $\mathrm{P}_{\mathrm{a}} \mathrm{O}_{2} / \mathrm{FiO}_{2}$ & $120(57-171 ; 114 \pm 42)$ & $118(73-259 ; 142 \pm 65)$ & $>0.05$ \\
\hline Age [years] & $62(59-71 ; 62.6 \pm 5.1)$ & $71(45-85 ; 69 \pm 12.2)$ & $>0.05$ \\
\hline Male [N;\%] & $9 / 10 ; 90 \%$ & $8 / 10 ; 80$ & \\
\hline $\mathrm{BMI}\left[\mathrm{kg} / \mathrm{m}^{2}\right]$ & $28.5(24-33 ; 28 \pm 3)$ & $27(22-56 ; 32 \pm 11.4)$ & $>0.05$ \\
\hline Norepinephrine & $4 / 10 ; 40 \%$ & $6 / 10 ; 60 \%$ & \\
\hline Hemoglobin $[\mathrm{g} / \mathrm{dL}]$ & $9.4(7.1-14 ; 10.0 \pm 2.2)$ & $9.5(7.1-12-2 ; 9.8 \pm 1.8)$ & $>0.05$ \\
\hline Leukocytes [G/L] & $9.45(6.1-24.1 ; 11 \pm 5)$ & $12.6(1.7-31.4 ; 14 \pm 8)$ & $>0.05$ \\
\hline Thrombocytes [G/L] & $186(71-320 ; 190 \pm 64)$ & $137(18-455 ; 165 \pm 129)$ & $>0.05$ \\
\hline CRP [mg/L] & $234(94-399 ; 233 \pm 115)$ & $104(35-447 ; 152 \pm 117)$ & $>0.05$ \\
\hline Creatinin [mg/dL] & $1.1(0.7-3.2 ; 1.3 \pm 0.7)$ & $1.9(0.5-4.6 ; 2.1 \pm 1.3)$ & $>0.05$ \\
\hline Bilirubin [mg/dL] & $1.2(0.3-7 ; 1.6 \pm 2)$ & $0.6(0.2-1.5 ; 0.7 \pm 0.4)$ & $>0.05$ \\
\hline Interleukin-6 [pg/mL] & $471(11-2397 ; 828 \pm 940)$ & n.a. & \\
\hline PCT [ng/mL] & $0.7(0.09-276 ; 28 \pm 87)$ & n.a. & \\
\hline
\end{tabular}

BMI Body mass index; CARDS COVID-19 associated ARDS CAP community acquired pneumonia; HAP Hospital acquired pneumonia SAPS Simplified acute physiology score; CRP C-reactive protein; NTproBNP N-terminal pro-B-type natriuretic peptide; PCT Procalcitonin;

\section{Characteristics of ventilation and blood gas analysis in COVID-19 and comparison to ARDS patients}

All patients received ventilation in a pressure-controlled mode. Plateau pressure was $25 \mathrm{cmH}_{2} \mathrm{O}$ (range 20-32) in CARDS and $23 \mathrm{cmH}_{2} \mathrm{O}$ (range 20-28) in ARDS patients. PEEP and $\triangle \mathrm{P}$ did not differ significantly between the two groups (CARDS PEEP: $10 \mathrm{cmH}_{2} \mathrm{O} ; \Delta \mathrm{P} 14 \mathrm{cmH}_{2} \mathrm{O}$ vs. ARDS PEEP $12 \mathrm{cmH}_{2} \mathrm{O}$; $\left.\triangle P 18 \mathrm{cmH}_{2} \mathrm{O} ; \mathrm{p}>0.05\right)$. Tidal volumes resulting from these pressure characteristics were $9 \mathrm{~mL} / \mathrm{kg}$ in CARDS vs. $8 \mathrm{~mL} / \mathrm{kg}$ in ARDS. None of the CARDS patients had tidal volumes less than $400 \mathrm{~mL}$ (median $613 \mathrm{~mL}$; range 415-994 mL). Higher tidal volume in CARDS patients was a result of better compliance in these patients. Lung compliance was $42 \mathrm{~mL} / \mathrm{cmH}_{2} \mathrm{O}$ (range $27-77 \mathrm{~mL} / \mathrm{cmH}_{2} \mathrm{O}$ ) in CARDS patients 
compared to $37 \mathrm{~mL} / \mathrm{cmH}_{2} \mathrm{O}$ (range $23-67 \mathrm{~mL} / \mathrm{cmH}_{2} \mathrm{O}$ ) in ARDS patients $(p>0.05)$. Only in four COVID-19 patients lung compliance was less than $40 \mathrm{~mL} / \mathrm{cmH}_{2} \mathrm{O} .50 \%$ of the patients needed a PEEP equal to or higher than $10 \mathrm{cmH}_{2} \mathrm{O}$ to maintain an adequate oxygenation. Gas exchange was different between groups CARDS and ARDS with higher $\mathrm{P}_{\mathrm{a}} \mathrm{CO}_{2}$ in the CARDS group ( $52 \mathrm{mmHg}$ vs. $41 \mathrm{mmHg} ; \mathrm{p}>0.05$ ), causing mild respiratory acidosis in CARDS ( $\mathrm{pH} 7.33$ vs. 7.46; $\mathrm{p}<0.05$ ) despite higher minute ventilation volume. The mechanical power applied by ventilation in CARDS patients was significantly higher than in ARDS patients $(p<0.05)$. Table 2 shows characteristics of ventilation in CARDS patients compared to patients with usual ARDS.

\section{Hemodynamic monitoring in CARDS vs. ARDS patients}

We compared pulmonary hemodynamics as assessed by pulmonary artery catheter in CARDS compared to ARDS patients (Table 3). Time between diagnosis of respiratory failure and PAC insertion was in median 13 days in CARDS patients. ARDS patients received PAC insertion in median 7 days from diagnosis. Time between intubation and PAC was 11 days (1-21 days) in CARDS patients and 3 (0-9 days) in ARDS patients $(p<0.05)$. This delay was mainly due to the fact that most CARDS patients were diagnosed with respiratory failure, intubated and transferred to our ICU from other hospitals.

Pulmonary arterial hypertension was common in both, CARDS and ARDS patients. Nine out of ten CARDS and ARDS patients had elevated mPAP values above $25 \mathrm{mmHg}$. Systolic and diastolic pulmonary arterial pressure did not differ between groups $(p>0.05)$. Both groups had partly post-capillary pulmonary hypertension with pulmonary capillary wedge pressures higher than $15 \mathrm{mmHg}$. ARDS patients had combined pre- and post-capillary pulmonary hypertension (PVR $>3 \mathrm{WU}, \mathrm{DPG} \geq 7$ ), while CARDS patients showed more isolated post-capillary pulmonary hypertension (median PVR $\leq 3 \mathrm{WU}$, median DPG $=$ $7 \mathrm{mmHg}$ ). Only one patient in the CARDS group showed DPG $\geq 7 \mathrm{mmHg}$ and PVR $>3 \mathrm{WU}$ meeting criteria of pre- and post-capillary pulmonary hypertension ${ }^{12}$. PEEP was not correlated with PVR in either group ( $p$ $>0.05$ ). The pulmonary vascular compliance $C_{P A}$ as part of right ventricular afterload, showed no significant difference, being $4.1 \mathrm{~mL} \times \mathrm{mmHg}^{-1}$ in CARDS patients vs. $2.8 \mathrm{~mL} \times \mathrm{mmHg}^{-1}$ in ARDS patients. There was a negative correlation between PVR and $C_{P A}$. The product of $P V R \times C_{P A}$ was thus similar between groups $(p>0.05)$, however the higher $C_{P A}$ in CARDS patients indicated sufficient RV-PA coupling. Indeed, no CARDS patient had right heart failure.

In both groups cardiac output was in a normal range. Patients with CARDS had significant higher cardiac output $(p<0.05)$ and slightly higher stroke volume $(p>0.05)$ than ARDS patients. Systemic vascular resistance (SVR) was significantly higher in patients with ARDS than in patients with CARDS $(p<0.05)$. No CARDS patient received inotropes. In the CARDS group 4 patients received norepinephrine during measurement and in the ARDS group 6 patients.

Physiological parameters derived from pulmonary artery catheter measurements and blood gas analysis in patients with CARDS and ARDS 
As patients with CARDS presented with elevated $\mathrm{p}_{\mathrm{a}} \mathrm{CO}_{2}$, we calculated the estimated $\mathrm{CO}_{2}$ production for both groups $\left(\mathrm{VCO}_{2 \text { est }}\right)$. Indeed, patients with CARDS had a statistically significantly higher estimated $\mathrm{CO}_{2}$ production. Hence, the statistically significant higher minute ventilation noted in CARDS patients could not compensate the higher production. Ventilatory ratio (VR) was higher in patients with CARDS, but the difference did not reach statistical significance. The same was true for physiological dead-space $\left(V_{D} / V_{T}\right)$. $V_{D} / V_{T}$ was strongly correlated with VR in patients with CARDS $(p<0.05$; Fig. $1 A)$, but not patients with ARDS. In CARDS patients, there was a negative correlation between $\mathrm{P}_{a} \mathrm{O}_{2} / \mathrm{F}_{i} \mathrm{O}_{2}$ and ventilatory ratio $(\mathrm{p}<$ 0.05 ; Fig. 1B). Calculated shunt fraction was not different between groups.

The ratio of the venous-arterial $\mathrm{CO}_{2}$ gap to arterial-venous oxygen content difference $\left(\mathrm{P}_{(\mathrm{v}-\mathrm{a})} \mathrm{CO}_{2} / \mathrm{C}_{(\mathrm{a}-\mathrm{v})} \mathrm{O}_{2}\right.$ ratio) was not different between groups, however patients with CARDS had a higher ratio than patients with ARDS (2.0 vs. 1.6). Additionally, the difference between central-venous and arterial $\mathrm{CO}_{2}\left(\triangle \mathrm{pCO}{ }_{2}\right)$ was different between groups, with a higher difference in CARDS patients (6.2 vs. $4.7 \mathrm{mmHg}$ ), but this difference did not reach statistical significance. Lactate levels, mixed venous oxygenation and alveolararterial Oxygen difference $\left(\mathrm{AaDO}_{2}\right)$ were similar in both groups. The parameters are summarized in Table 4.

Table 4

Physiological parameters derived from measurements in CARDS patients $(N=10)$ and ARDS of other causes $(\mathrm{N}=10)$ acquired Swan-Ganz catheterization and blood gas analysis. Barometric pressure was recorded on the day of the actual Swan-Ganz catheterization.

\begin{tabular}{|c|c|c|c|}
\hline Variable & $\begin{array}{l}\text { CARDS; } N=10 \\
\text { median (range; mean } \pm S D \text { ) }\end{array}$ & $\begin{array}{l}\text { ARDS; } N=10 \\
\text { median (range; mean } \pm S D \text { ) }\end{array}$ & p-value \\
\hline $\mathrm{P}_{(\mathrm{v}-\mathrm{a})} \mathrm{CO}_{2} / \mathrm{C}_{(\mathrm{a}-\mathrm{v})} \mathrm{O}_{2}$ & $2.0(0.5-5.6 ; 2.2 \pm 1.5)$ & $1.6(0.3-3.3 ; 1.7 \pm 0.8)$ & $>0.05$ \\
\hline$\Delta \mathrm{pCO}_{2}[\mathrm{mmHg}]$ & $6.2(1.2-9.8 ; 5.5 \pm 2.8)$ & $4.7(2.5-5.3 ; 4.7 \pm 1.1)$ & $>0.05$ \\
\hline $\mathrm{s}_{\mathrm{v}} \mathrm{O}_{2}[\%]$ & $73(69-79 ; 73 \pm 3)$ & $68(46-79 ; 68 \pm 9.6)$ & $>0.05$ \\
\hline Lactate (art.) & $1.4(0.7-1.9 ; 1.4 \pm 0.3)$ & $2.1(0.6-3.4 ; 2 \pm 1)$ & $>0.05$ \\
\hline $\mathrm{AaDO}_{2}[\mathrm{mmHg}]$ & $278(30-551 ; 298 \pm 146)$ & $298(79-546 ; 282 \pm 159)$ & $>0.05$ \\
\hline $\mathrm{VCO}_{2 \text { est }}[\mathrm{mL} / \mathrm{min}]$ & $347(220-382 ; 336 \pm 47)$ & $277(217-374 ; 287 \pm 51)$ & $<0.05$ \\
\hline VE [L/min] & $13.0(6.7-20.3 ; 13.4 \pm 4.2)$ & $10.5(7.5-13.2 ; 10.1 \pm 2)$ & $<0.05$ \\
\hline Ventilatory ratio & $1.9(1.0-3.2 ; 2.0 \pm 0.8)$ & $1.5(0.8-2.6 ; 1.5 \pm 0.6)$ & $>0.05$ \\
\hline Shunt Fraction [\%] & $23(8-50 ; 26 \pm 13)$ & $19(7-55 ; 23 \pm 15)$ & $>0.05$ \\
\hline $\mathrm{V}_{\mathrm{D}} / \mathrm{V}_{\mathrm{T}}[\%]$ & $50(11-69 ; 46 \pm 20)$ & $41(10-68 ; 43 \pm 18)$ & $>0.05$ \\
\hline
\end{tabular}


Table 2: Mechanical ventilation characteristics of CARDS patients $(n=10)$ compared to mechanical ventilation characteristics of patients with ARDS $(n=10)$.

\begin{tabular}{|c|c|c|c|}
\hline Patient characteristics & $\begin{array}{l}\text { CARDS; } N=10 \\
\text { median (range; mean } \pm \text { SD) }\end{array}$ & $\begin{array}{l}\text { ARDS; } N=10 \\
\text { median (range; mean } \pm \text { SD) }\end{array}$ & $P$ value \\
\hline Body temperature $\left[{ }^{\circ} \mathrm{C}\right]$ & $38.5(38.1-39.3 ; 38.6 \pm 0.3)$ & $\begin{array}{l}37.4(36.2-38.2 ; 37.3 \pm \\
0.7)\end{array}$ & $<0.05$ \\
\hline Compliance $\left[\mathrm{mL} / \mathrm{cmH}_{2} \mathrm{O}\right]$ & $42(27-77 ; 44 \pm 17)$ & $37(23-67 ; 39 \pm 13)$ & $>0.05$ \\
\hline PEEP $\left[\mathrm{cmH}_{2} \mathrm{O}\right]$ & $10(8-14 ; 10 \pm 2.3)$ & $10(5-14 ; 9 \pm 3)$ & $>0.05$ \\
\hline$\Delta \mathrm{P}\left[\mathrm{P}_{\text {plat }}-\mathrm{PEEP}\right]$ & $14(12-22 ; 16 \pm 3.7)$ & $15(8-18 ; 15 \pm 3.2)$ & $>0.05$ \\
\hline Respiratory rate [/min] & $18(11-36 ; 21 \pm 8)$ & $18(16-22 ; 19 \pm 2)$ & $>0.05$ \\
\hline $\mathrm{Vt}[\mathrm{mL} / \mathrm{kg}]$ & $9(5-14 ; 9 \pm 2.4)$ & $8(6-10 ; 8 \pm 1.1)$ & $<0.05$ \\
\hline $\mathrm{VE}[\mathrm{L} / \mathrm{min}]$ & $13.0(6.7-20.3 ; 13.4 \pm 4.2)$ & $10.5(7.5-13.2 ; 10.1 \pm 2)$ & $<0.05$ \\
\hline $\begin{array}{l}\text { Mechanical power } \\
{[\mathrm{J} / \mathrm{min}]}\end{array}$ & $20.8(12.2-38.3 ; 23.4 \pm 8.9)$ & $\begin{array}{l}14.1(11.8-23.9 ; 15.9 \pm \\
4.3)\end{array}$ & $<0.05$ \\
\hline $\mathrm{P}_{\mathrm{a}} \mathrm{O}_{2}[\mathrm{mmHg}]$ & $77(57-97 ; 75 \pm 14)$ & $75(67-115 ; 83 \pm 16.5)$ & $>0.05$ \\
\hline $\mathrm{P}_{\mathrm{a}} \mathrm{CO}_{2}[\mathrm{mmHg}]$ & $52(33-74 ; 51 \pm 12)$ & $41(26-73 ; 43 \pm 12)$ & $>0.05$ \\
\hline $\mathrm{pH}$ & $\begin{array}{l}7.33(7.29-7.43 ; 7.33 \pm \\
0.05)\end{array}$ & $\begin{array}{l}7.42(7.32-7.53 ; 7.43 \pm \\
0.1)\end{array}$ & $<0.05$ \\
\hline
\end{tabular}

Abbreviations: CARDS Covid19-related acute respiratory distress syndrome; PEEP Positive end expiratory pressure; $\Delta \mathrm{P}$ Difference between plateau pressure and PEEP; Vt Tidal volume; MV Minute volume; Compliance in $\mathrm{mL} / \mathrm{cmH} 20$;

Table 3: Invasive Hemodynamics acquired by pulmonary artery of CARDS patients $(\mathrm{N}=10)$ compared to ARDS of other causes $(N=10)$. Differences in time from intubation to PAC is due to the fact that most patients with CARDS were referred to our center. 


\begin{tabular}{|c|c|c|c|}
\hline Variable & $\begin{array}{l}\text { CARDS; } N=10 \\
\text { median (range; mean } \pm S D \text { ) }\end{array}$ & $\begin{array}{l}\text { ARDS; } N=10 \\
\text { median (range; mean } \pm S D \text { ) }\end{array}$ & $\begin{array}{l}\mathrm{p}- \\
\text { value }\end{array}$ \\
\hline $\begin{array}{l}\text { Days from intubation to } \\
\text { PAC }\end{array}$ & $11(1-21 ; 10 \pm 6)$ & $3(10-9 ; 3 \pm 2.9)$ & $<0.05$ \\
\hline $\mathrm{P}_{\mathrm{a}} \mathrm{O}_{2} / \mathrm{F}_{\mathrm{i}} \mathrm{O}_{2}$ ratio & $120(57-171 ; 114 \pm 42)$ & $134(73-259 ; 149 \pm 62.1)$ & $>0.05$ \\
\hline PAPs [mmHg] & $53(23-62 ; 47 \pm 13.3)$ & $46(27-61 ; 44 \pm 9)$ & $>0.05$ \\
\hline PAPd [mmHg] & $24(11-31 ; 23 \pm 6.1)$ & $25(15-34 ; 25 \pm 5.5)$ & $>0.05$ \\
\hline PAPm $[\mathrm{mmHg}]$ & $36(16-44 ; 32 \pm 8)$ & $34(20-46 ; 33 \pm 6.8)$ & $>0.05$ \\
\hline PCWP [mmHg] & $18(8-26 ; 17 \pm 5.9)$ & $16(9-28 ; 17 \pm 6.8)$ & $>0.05$ \\
\hline PVR $\left[d y n^{\star} S^{*} c m-5\right]$ & $133(13-329 ; 139 \pm 77)$ & $248(101-385 ; 242 \pm 89.2)$ & $<0.05$ \\
\hline $\begin{array}{l}\text { WU*m² } \\
{\left[\mathrm{mmHg} / \mathrm{L} / \mathrm{min} / \mathrm{m}^{2}\right]}\end{array}$ & $1.7(0.2-4.1 ; 1.7 \pm 1)$ & $3.1(1.3-4.8 ; 3 \pm 1.1)$ & $<0.05$ \\
\hline DPG $[\mathrm{mmHg}]$ & $7(1-10 ; 6 \pm 5)$ & $8(3-19 ; 7 \pm 4.6)$ & $>0.05$ \\
\hline $\mathrm{C}_{\mathrm{PA}}[\mathrm{mL} / \mathrm{mmHg}]$ & $4.1(2-11 ; 4.6 \pm 2.4)$ & $2.8(2-6.1 ; 3.3 \pm 1.3)$ & $>0.05$ \\
\hline $\mathrm{C}_{\mathrm{PAx}} \mathrm{PVR}(\tau)$ in seconds & $7.3(0.9-11.9 ; 6.9 \pm 3.1)$ & $9.0(3.3-16.6 ; 9.1 \pm 3.3)$ & $>0.05$ \\
\hline $\mathrm{SVR}\left[\mathrm{mmHg}^{\star} \mathrm{min}^{\star} \mathrm{ml}^{-1}\right]$ & $\begin{array}{l}783(515-1,171 ; 801 \pm \\
168)\end{array}$ & $\begin{array}{l}1,374(539-1,985 ; 1,240 \pm \\
481)\end{array}$ & $<0.05$ \\
\hline $\mathrm{CO}[\mathrm{L} / \mathrm{min}]$ & $7.8(6.4-11.8 ; 8.1 \pm 1.7)$ & $5(1.9-8.5 ; 5.4 \pm 1.5)$ & $<0.05$ \\
\hline $\mathrm{Cl}\left[\mathrm{L} / \mathrm{min} / \mathrm{m}^{2}\right]$ & $3.9(2.7-6.4 ; 4.1 \pm 1.1)$ & $2.7(1.7-3.8 ; 2.7 \pm 0.7)$ & $<0.05$ \\
\hline $\mathrm{SV}[\mathrm{mL}]$ & $95(60-126 ; 95 \pm 19)$ & $50(36-117 ; 61 \pm 23.4)$ & $<0.05$ \\
\hline NT-proBNP [pg/mL] & $\begin{array}{l}365(70-77,275 ; 336 \pm \\
23,082)\end{array}$ & $\begin{array}{l}2671(264-50,403 ; 8,996 \pm \\
14,462)\end{array}$ & $>0.05$ \\
\hline
\end{tabular}

Abbreviations: CARDS Covid19-related acute respiratory distress syndrome; SAPS Simplified acute physiological score; PAPs Systolic pulmonary arterial pressure; PAPd Diastolic pulmonary arterial pressure; PAPm Median pulmonary arterial pressure; PCWP Pulmonary capillary wedge pressure; PVR Pulmonary vascular resistance; SVR Systemic vascular resistance; CO Cardiac output; CI Cardiac index; $\mathrm{C}_{\mathrm{PA}}$ Pulmonary artery compliance. 


\section{Discussion}

The present study compared patients with CARDS to patients with ARDS. The main findings of our study are: i) the pulmonary hemodynamic is not profoundly altered in CARDS compared to usual ARDS and ii) auto-regulation of lung vessels seems to be largely intact in patients with SARS-CoV2-related lung failure, iii) mechanical ventilation intensity was statistically significant higher in CARDS compared to usual ARDS.

Usual ARDS is defined by decreased diffusion capacity and ventilation deficit as a consequence of inflammation and low compliance ${ }^{7}$, resulting in a "baby lung". In addition, there is often pulmonary hypertension due to increased vascular resistance with the risk of consecutive right heart failure ${ }^{4}$. In COVID-19 patients admitted to our ICU we could not completely affirm these pathophysiological findings.

Further $\mathrm{p}_{\mathrm{a}} \mathrm{CO}_{2}$ in COVID-19 patients was rather similar compared to patients with ARDS at $52 \mathrm{mmHg}$ and $41 \mathrm{mmHg}$, respectively. Our data shows that all COVID-19 patients had tidal volumes and a compliance resulting in minute ventilation of $6 \mathrm{~L} / \mathrm{min}$ to $20 \mathrm{~L} / \mathrm{min}$. These findings might not be typical for patients with ARDS. In these patients tidal volume is low for the compliance of the lung is decreased ${ }^{13}$. As $\mathrm{CO}_{2}$ has a higher diffusion coefficient than $\mathrm{O}_{2}$, hypercapnia is normally a problem of ventilation rather than diffusion ${ }^{14}$. In usual ARDS, patients hypercapnia can be explained by low tidal volume and the following lack of alveolar ventilation. But in CARDS patients minute ventilation was not decreased. Our group of CARDS patients had significantly higher tidal volume and a higher compliance than ARDS patients. Matching these two groups by $\mathrm{P}_{\mathrm{a}} \mathrm{O}_{2}$ and oxygenation index, these parameters were quite similar in both groups. The question that arises is the pathophysiology behind the hypercapnia despite high minute ventilation and preserved compliance. V/Q mismatch could be an explanation for the ineffective gas exchange in CARDS patients. Also, non-effective regulation of hypoxic vasoconstriction ${ }^{10}$ could be another reason why blood volume passes non-ventilated areas in the lungs and is not able to participate in gas exchange. However, we could not find differences between CARDS and ARDS with regard to calculated physiological dead-space and shunt fraction. Calculated dead-space in CARDS and ARDS patients was in the range expected according to $\mathrm{P}_{\mathrm{a}} \mathrm{O}_{2} / \mathrm{F}_{i} \mathrm{O}_{2}$ ratio ${ }^{15}$. However, we found a significant difference in the estimated $\mathrm{CO}_{2}$ production, which might explain at least some of the CARDS features. Indeed, the intensity of ventilation was significantly higher in CARDS patients than ARDS patients, but the intensity in CARDS patients was not surprisingly high and comparable to previously reported data in patients with ARDS ${ }^{16}$.

In ARDS patients there is often pulmonary hypertension as consequence of hypoxia or hypercapnia. Further, there is a higher rate of right heart failure and lower cardiac output in ARDS patients because of a higher right ventricular afterload ${ }^{17,18}$. In CARDS patients we did not see signs of right heart failure or decreased cardiac output. The cardiac output in CARDS patients was $7.8 \mathrm{~L} / \mathrm{min}$ in median compared to 6.1 L/min in ARDS patients (cardiac index $3.9 \mathrm{~L} / \mathrm{min} / \mathrm{m}^{2}$ vs. $3.1 \mathrm{~L} / \mathrm{min} / \mathrm{m}^{2}$ ). Pulmonary vascular resistance was significantly lower in CARDS patients than in ARDS patients $\left(133 \mathrm{dyn} \times \mathrm{sec} \times \mathrm{cm}^{-5}\right.$ in 
COVID-19 vs. $248 \mathrm{dyn} \times \sec \times \mathrm{cm}^{-5}$ in ARDS patients). One reason for increased PVR is higher PEEP. It has been shown previously, that increasing the PEEP increases PVR in mechanically ventilated patients ${ }^{19}$. In our study, PEEP was similar in both groups and also pulmonary capillary wedge-pressure did not differ and there was no correlation between PEEP and PVR. The difference in PVR may thus simply result from increased cardiac output of CARDS patients. CARDS patients probably had an increased cardiac output in comparison to ARDS patients due to inflammation and low systemic vascular resistance.

Mean pulmonary arterial pressure was similar in COVID-19 patients and in patients with ARDS, nevertheless both groups showed pulmonary arterial hypertension to some degree. Both groups had postcapillary forms of pulmonary hypertension with PCWP $>15 \mathrm{mmHg}$, but the diastolic pressure gradient was $7 \mathrm{mmHg}$ in median in CARDS patients vs. $8 \mathrm{mmHg}$ in ARDS patients. With a DPG less than $7 \mathrm{mmHg}$ there is no precapillary component in pulmonary hypertension according to the actual guidelines ${ }^{12}$. In our study, the median DPG was $7 \mathrm{mmHg}$ and PVR $1.7 \mathrm{WU} \times \mathrm{m}^{2}$ (vs. DPG $8 \mathrm{mmHg}$, PVR $3.1 \mathrm{WU} \times \mathrm{m}^{2}$ in ARDS) meaning the pulmonary arterial hypertension in CARDS may be more a result of a post-capillary component, than a precapillary. Hence, there was only a slight difference and a defect in pulmonary vascular regulation in the presence of hypoxemia and hypercapnia unable to avoid a pathologically high right-left shunt ${ }^{20}$ can be ruled out. We did not calculate an unexpected high shunt in CARDS patients. Rather, an elevated $\mathrm{CO}_{2}$ production might explain differences between CARDS and ARDS. Patients presented with prolonged fever and unexpected long periods of elevated inflammatory parameters, both might contribute to increased $\mathrm{VCO}_{2}$.

Early recommendations for COVID-19 patients with respiratory failure consisted in early invasive ventilation strategies to avoid contagious aerosols and the use of high PEEP analogue to usual ARDS ${ }^{21}$. These therapies may be most effective in patients with lower diffusion capacity and compliance but the benefit in ventilation/perfusion mismatch needs to be questioned. These recommendations may be effective in ARDS patients, however in CARDS patients an important cornerstone according to our data might be to limit excessive $\mathrm{CO}_{2}$ production e.g. by rigorous temperature control.

Moreover veno-venous extracorporeal life support (vVECMO) should be considered to treat these patients. Six patients in the CARDS group recieved vvECMO therapy later on, because of increasing hypercapnia and $\mathrm{pH}<7.1$ at exhausted mechanical ventilation.

\section{Limitations}

Our study has several limitations that need to be considered. First, the sample size of this analysis is relatively small. However, PAC is only used in special situations in ARDS patients in clinical routine, rendering sample sizes small. Differences between groups in important values might be more pronounced, if sample size was bigger. A critical parameter like $\mathrm{P}_{(\mathrm{v}-\mathrm{a})} \mathrm{CO}_{2} / \mathrm{C}_{(\mathrm{a}-\mathrm{v})} \mathrm{O}_{2}$ might in fact reach statistical significance in larger samples. The fact that SARS-CoV-2 is still causing a global pandemic could be a favour in recruiting more patients. 
Second, the comparator group for pulmonary hemodynamics could be more consistent and homogeneous. We compared hemodynamics of COVID-19 patients with ARDS that was not exclusively due to viral infection. However, hypoxic pulmonary vasoconstriction has been expected to work independently of a causative organism in the past.

Third, the time of PAC insertion in CARDS patients was distinctly later than in ARDS patients and measurement was only at one point in time. This was mainly due to the fact that as a tertiary care centre, we received patients with COVID-19 in the beginning of the pandemia from other hospitals where patients had already been treated for several days on ICUs. It seems that COVID-19 has different phenotypes according to the time of evaluation being less usual at the beginning and adopting a more usual phenotype after days of mechanical ventilation. Interestingly, despite the differences in time, we couldn't detect relevant differences between groups. Possibly, pathophysiology in COVID-19 is simply prolonged as compared to other respiratory diseases.

\section{Conclusion}

Our data do not support the assumption that CARDS (at a later stage) leads to changes in pulmonary vasculature distinct from ARDS due to pulmonary infections. Mechanical power applied to the lung of CARDS patients by ventilation was significantly higher than in ARDS patients. The data presented here could be useful to guide CARDS therapy, as we assume that the results apply also for other cohorts of patients with severe SARS-CoV2 infection. Further investigations are needed to elucidate the mechanisms behind SARS-CoV2 induced pulmonary pathology.

\section{Declarations}

\section{Ethics approval and consent to participate}

Informed consent for pulmonary artery catheterization as part of standard intensive care was obtained by the patient or legal representative. The institutional review board (Ärztekammer des Saarlandes) registered the study, to use a PAC in patients with ARDS, irrespective of the infectious agent, in 2019 under the number 278/19. Informed consent for the analysis of data is waived by the institutional review board due to the anonymous and retrospective analysis of data.

\section{Consent for Publication}

Not applicable.

\section{Availability of data and materials}

Data can be provided on request addressed to the corresponding author. All data sharing statements are subject to conformity with German data protection legislation and rules (Datenschutzgrundverordnung DGSVO). 


\section{Competing interests}

R.B. received funding from AstraZeneca, Boehringer Ingelheim, GlaxoSmithKline, Grifols, Novartis, CSL Behring, German Federal Ministry of Education and Research (BMBF) Competence Network, Sander Stiftung, Dr. Rolf M. Schwiete Foundation, German Cancer help (Krebshilfe) and Mukoviszidose e.V. All other authors have no conflicts of interest to declare.

\section{Funding}

COVID-19 research at the University Hospital of Saarland is funded by unrestricted grants of the Federal State of Saarland, Saarland University and Dr. Rolf M. Schwiete Foundation. The funders had no role with regard to this study in the design of the study and collection, analysis, and interpretation of data and in writing the manuscript.

\section{Author's Contribution}

A.B., F.S., G.D., S.M., A.O., C.J., M.K. Ho.W., T.M. and P.M.L. contributed to collection, review, and/or analysis of the data; A.B. and P.M.L. drafted the manuscript, R.M.M., C.L., He.W., and R.B. revised the manuscript for important intellectual content. All authors have seen and approved the final version of the manuscript. P.M.L. is the guarantor of the manuscript.

\section{Acknowledgement}

Not applicable.

\section{References}

1. Grasselli G, Zangrillo A, Zanella A, et al. Baseline Characteristics and Outcomes of 1591 Patients Infected With SARS-CoV-2 Admitted to ICUs of the Lombardy Region, Italy. JAMA 2020.

2. Marini JJ, Gattinoni L. Management of COVID-19 Respiratory Distress. JAMA 2020.

3. Varga Z, Flammer AJ, Steiger P, et al. Endothelial cell infection and endotheliitis in COVID-19. Lancet 2020;395:1417-8.

4. Zapol WM, Snider MT. Pulmonary hypertension in severe acute respiratory failure. N Engl J Med 1977;296:476-80.

5. Ashbaugh DG, Bigelow DB, Petty TL, Levine BE. Acute respiratory distress in adults. Lancet 1967;2:319-23.

6. Beiderlinden $\mathrm{M}$, Kuehl $\mathrm{H}$, Boes T, Peters J. Prevalence of pulmonary hypertension associated with severe acute respiratory distress syndrome: predictive value of computed tomography. Intensive Care Med 2006;32:852-7.

7. Ferguson ND, Fan E, Camporota L, et al. The Berlin definition of ARDS: an expanded rationale, justification, and supplementary material. Intensive Care Med 2012;38:1573-82. 
8. Roza AM, Shizgal HM. The Harris Benedict equation reevaluated: resting energy requirements and the body cell mass. Am J Clin Nutr 1984;40:168-82.

9. Sinha P, Fauvel NJ, Singh S, Soni N. Ventilatory ratio: a simple bedside measure of ventilation. $\mathrm{Br} \mathrm{J}$ Anaesth 2009;102:692-7.

10. Acute Respiratory Distress Syndrome N, Brower RG, Matthay MA, et al. Ventilation with lower tidal volumes as compared with traditional tidal volumes for acute lung injury and the acute respiratory distress syndrome. N Engl J Med 2000;342:1301-8.

11. Force ADT, Ranieri VM, Rubenfeld GD, et al. Acute respiratory distress syndrome: the Berlin Definition. JAMA 2012;307:2526-33.

12. Galie N, Humbert M, Vachiery JL, et al. 2015 ESC/ERS Guidelines for the diagnosis and treatment of pulmonary hypertension: The Joint Task Force for the Diagnosis and Treatment of Pulmonary Hypertension of the European Society of Cardiology (ESC) and the European Respiratory Society (ERS): Endorsed by: Association for European Paediatric and Congenital Cardiology (AEPC), International Society for Heart and Lung Transplantation (ISHLT). Eur Respir J 2015;46:903-75.

13. Hager DN, Krishnan JA, Hayden DL, Brower RG, Network ACT. Tidal volume reduction in patients with acute lung injury when plateau pressures are not high. Am J Respir Crit Care Med 2005;172:1241-5.

14. Petersson J, Glenny RW. Gas exchange and ventilation-perfusion relationships in the lung. Eur Respir J 2014;44:1023-41.

15. Radermacher P, Maggiore SM, Mercat A. Fifty Years of Research in ARDS. Gas Exchange in Acute Respiratory Distress Syndrome. Am J Respir Crit Care Med 2017;196:964-84.

16. Wang R, Sun B, Li X, et al. Mechanical Ventilation Strategy Guided by Transpulmonary Pressure in Severe Acute Respiratory Distress Syndrome Treated With Venovenous Extracorporeal Membrane Oxygenation. Crit Care Med 2020.

17. Mekontso Dessap A, Boissier F, Charron C, et al. Acute cor pulmonale during protective ventilation for acute respiratory distress syndrome: prevalence, predictors, and clinical impact. Intensive Care Med 2016;42:862-70.

18. Zochios V, Parhar K, Tunnicliffe W, Roscoe A, Gao F. The Right Ventricle in ARDS. Chest 2017;152:181-93.

19. Tyberg JV, Grant DA, Kingma I, et al. Effects of positive intrathoracic pressure on pulmonary and systemic hemodynamics. Respir Physiol 2000;119:171-9.

20. Dunham-Snary KJ, Wu D, Sykes EA, et al. Hypoxic Pulmonary Vasoconstriction: From Molecular Mechanisms to Medicine. Chest 2017;151:181-92.

21. Alhazzani W, Moller MH, Arabi YM, et al. Surviving Sepsis Campaign: guidelines on the management of critically ill adults with Coronavirus Disease 2019 (COVID-19). Intensive Care Med 2020;46:854-87.

\section{Figures}



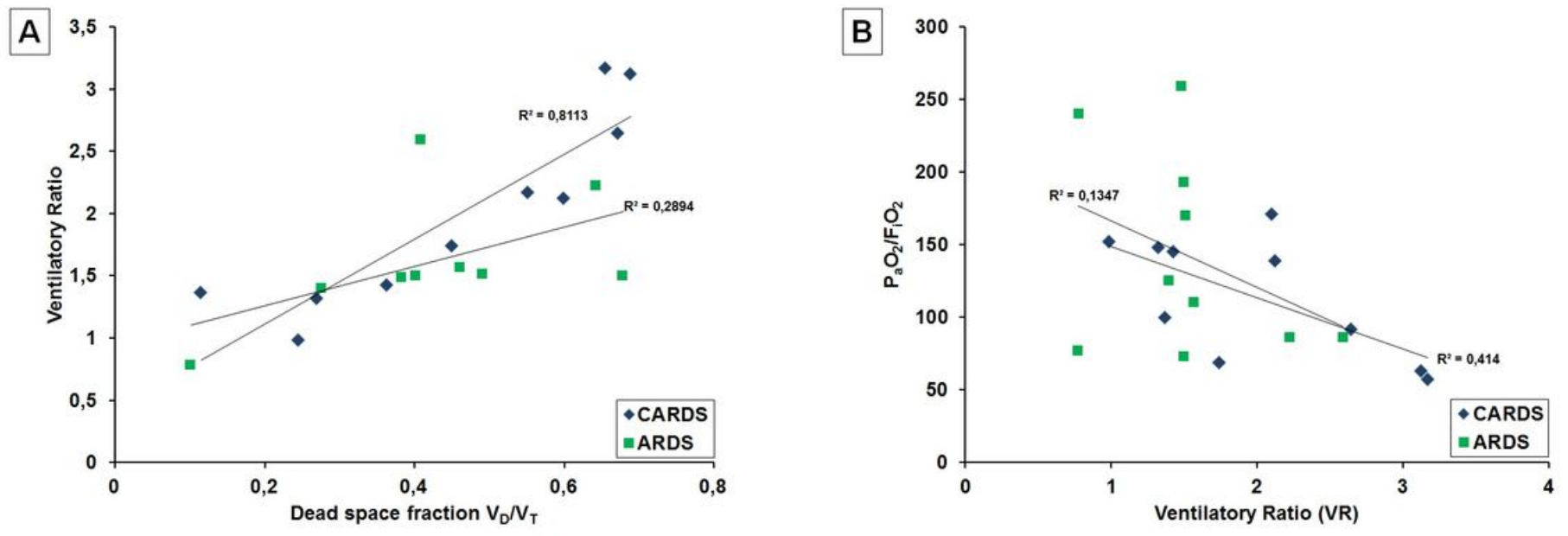

Figure 1

Correlation between ventilatory ratio (VR) and dead space fraction (VD/VT). There was a statistically significant association between VR and VD/VT in CARDS patients $(p<0.05)$. (B): Correlation between $\mathrm{PaO} 2 / \mathrm{FiO} 2$ ratio and VR. 